\title{
A double blind trial to assess the value of alclofenac compared with phenylbutazone in the management of rheumatoid arthritis
}

\author{
M. A. CHAMBERLAIN AND V. WRIGHT \\ From the Departments of Rheumatology and Rehabilitation, General Infimary at Leeds
}

\begin{abstract}
Chamberlain, M. A., and Wright, V. (1975). Annals of the Rheumatic Diseases, 34, 186. A double blind trial to assess the value of alclofenac compared with phenylbutazone in the management of rheumatoid arthritis. (1) A double-blind cross-over study using a double placebo technique was employed to compare the effectiveness of daily alclofenac $3 \mathbf{g}$ and phenylbutazone $300 \mathrm{mg}$ in rheumatoid arthritis. (2) Thirty-one patients with classical or definite rheumatoid arthritis entered the trial. Twenty-three patients completed the trial; eight patients were withdrawn while on alclofenac, six developing a rash and two having inadequate analgesia. (3) Relief of pain on both drugs was comparable. (4) When questioned at the end of the trial, sixteen patients preferred phenylbutazone, four preferred alclofenac. (5) No significant changes in laboratory values were found, apart from a slight mean fall in haemoglobin on phenylbutazone. (6) There were significantly more side effects on alclofenac and rashes were particularly prominent.
\end{abstract}

A double-blind cross-over controlled trial was set up to compare the analgesic value of alclofenac (Prinalgin) with phenylbutazone in rheumatoid arthritis.

Alclofenac, 4-allyloxy-3-chlorophenylacetic acid, is a derivative of phenylacetic and found to have a high degree of analgesic activity in animals. It is also said to be anti-inflammatory and antipyretic and to be less irritant to the gastrointestinal mucosa than phenylbutazone or indomethacin (Van Hoek, 1970).

The drug is absorbed from the intestinal wall in its original state; it reaches plateau level in the blood in 2-3 hours and is excreted in 24 hours (Roncucci, Simon, Lambelin, Saquet, Gillet, van Cauwenberge, Lefébvre, Daubresse, and Buu-Hoi, 1971); $1.5 \mathrm{~g}$ alclofenac has been assessed as being equivalent in analgesic potential to $300 \mathrm{mg}$ phenylbutazone (Van Hoek, 1970).

The trial was designed to assess the analgesic efficiency of alclofenac; information on the incidence of side effects was also sought and simple laboratory tests of haematological state and of renal function were made.

\section{Materials and methods}

Outpatients of either sex who had definite or classical rheumatoid arthritis according to the A.R.A. criteria who were aged between 17 and 75 years were eligible for ad-

Accepted for publication August 13, 1974. mission to the trial. Patients stabilized on small doses of corticosteroids ( $<10 \mathrm{mg} /$ day) or Myocrisin were included in the trial, as were patients with a normal ESR and/or a negative sheep cell agglutination titre. However, known sensitivity to any of the drugs used in the trial, treatment with antimalarial drugs, serious renal, cardiac, or hepatic disease, pregnancy, past or present peptic ulceration excluded a patient from entering.

The trial was conducted as a double-blind cross-over study with a double placebo technique (Wright, Walker, and McGuire, 1969). Each patient had a preliminary fortnight on paracetamol $1.5 \mathrm{~g}$ q.d.s. After this, patients received either (a) alclofenac $1 \mathrm{~g}$ t.d.s. with phenylbutazone placebo t.d.s. or (b) alclofenac placebo t.d.s. and phenylbutazone $100 \mathrm{mg}$ t.d.s. After one month the drug combinations were reversed. Treatment for each person was decided by a predetermined random code. Each active drug looked like and tasted similar to its placebo. Each patient was given more tablets than he should need in the treatment period and the number of tablets left over was recorded at each visit. Fifty paracetamol tablets were also given with each prescription, with instructions that they were only to be used if other tablets were insufficiently strong; no other analgesics were permitted. Assessments were made at day zero, at the end of the first period of treatment (day 28), and at the end of the second period (day 56).

CLINICAL ASSESSMENTS

At the first assessment a list of possible side effects was read to the patient and those present recorded, and a sheep cell agglutination test performed. 
At all assessment visits note was kept of the duration of morning stiffness and the patient's assessment of pain (none $=0$; mild $=1$; moderate $=2$; severe $=3$; agonizing =4), and progress (much worse $=1$; worse $=2$; same $=3$; better $=4$; much better $=5$ ). The average daily consumption of paracetamol and the mean of three recordings of maximum grip strength in each hand were also recorded. Each subject was asked, 'Have the tablets upset you in any way?' Blood was then taken for measurement of glucose, plasma proteins, urea, electrolytes, haemoglobin, white cell count, and erythrocyte sedimentation rate (ESR). Urine was tested for sugar, albumin, ketones, and blood.

To prevent bias, results were written on a separate tear-off sheet for each visit. At the last visit the patient was asked which month's treatment he preferred; if neither was thought helpful he was then asked which of his previous analgesic regimens he wished reinstated.

\section{Results}

WITHDRA WALS

Thirty-one patients entered the trial. Eight of these were later withdrawn, all while receiving alclofenac treatment, six because of rashes and two because of inadequate analgesia. The latter two had already worsened on the pretrial paracetamol compared with their usual medication.

In a few cases laboratory data were incomplete; in these cases the patients have been excluded from the relevant analysis.

\section{CHARACTERISTICS OF THE PRESENTING POPULATION}

Fourteen of the twenty-three patients completing the trial received active phenylbutazone first, followed by alclofenac; the other nine received alclofenac first.

Eleven patients had definite rheumatoid arthritis, twelve had classical disease (10 patients had nodules and 21 had none. Duration of disease varied from 1 to 20 years, the mean being 9 years. Rheumatoid factor was present in $71 \%$.
Other mean initial characteristics were as follows: pain grade 1.9; mean maximum grip strength 125.5 (standard deviation 72.6); haemoglobin $12.7 \mathrm{~g} / \mathrm{dl}$; white cell count $7.9 \times 10^{3}$ cells $/ \mathrm{mm}^{3}$; ESR $26 \mathrm{mmHg}$ in first hour; blood glucose $4.1 \mathrm{mmol} / 1(73.9 \mathrm{mg} / 100$ $\mathrm{ml}$ ); serum protein $81 \mathrm{~g} / \mathrm{l}$ (albumin $42 \mathrm{~g} / \mathrm{l}$, globulin $39.5 \mathrm{~g} / \mathrm{l})$; blood urea $5.6 \mathrm{mmol} / \mathrm{l}(34 \mathrm{mg} / 100 \mathrm{ml})$; sodium $139 \mathrm{mmol} / \mathrm{l}(139 \mathrm{mEq} / \mathrm{l})$; potassium $4 \cdot 1$ $\mathrm{mmol} / \mathrm{l}(4 \cdot 1 \mathrm{mEq} / \mathrm{l})$; carbonate $22 \cdot 8 \mathrm{mmol} / \mathrm{l}$.

\section{COMPARISON OF RESULTS ON ALCLOFENAC AND PHENYLBUTAZONE}

A straight comparison between the two drugs was made. Thus five patients experienced more pain on alclofenac compared with eleven on phenylbutazone; ten patients improved on alclofenac compared with seven on phenylbutazone. These results are not significantly different $\left(\chi^{2}=3 \cdot 4717\right)$. Neither group showed any significant improvement over the score after the paracetamol run-in (Table I).

\section{PATIENTS' ASSESSMENT OF PROGRESS}

Patients were asked, 'In comparison with the previous 2 weeks is your pain now much worse/worse/better/ much better?' (Table II). Progress was significantly greater on phenylbutazone compared with alclofenac $\left(\chi^{2}=7.0462 ; 0.05>P>0.02\right)$. No progress had been made when patients changed from paracetamol to alclofenac. When average consumption of paracetamol was compared no difference was revealed between the groups $(455 \mathrm{mg} /$ day on alclofenac and $350 \mathrm{mg}$ /day on phenylbutazone).

Similarly, no statistically significant differences were found between the numbers of tablets remaining after each treatment was completed. The average duration of stiffness on alclofenac was $114 \mathrm{~min}$, on phenylbutazone $72 \mathrm{~min}$, but the difference was not significant. Mean maximum grip strength on alclofenac was $123.6 \mathrm{mmHg}$ compared with $131.7 \mathrm{mmHg}$

Table I Comparison of results on alclofenac and phenylbutazone

\begin{tabular}{|c|c|c|c|c|c|}
\hline Pain & Much worse (0) & Worse (I) & Same (2) & Better (3) & Much better (4) \\
\hline $\begin{array}{l}\text { Alclofenac } \\
\text { Phenylbutazone }\end{array}$ & $\begin{array}{l}0 \\
2\end{array}$ & $\begin{array}{l}5 \\
9\end{array}$ & $\begin{array}{l}8 \\
5\end{array}$ & $\begin{array}{r}10 \\
6 .\end{array}$ & $\begin{array}{l}0 \\
1\end{array}$ \\
\hline
\end{tabular}

Table II Patients' assessment of progress

\begin{tabular}{|c|c|c|c|}
\hline Progress grade & Much Worse $\underset{1}{\text { worse }}$ & Same & $\underset{4}{\text { Better }}+\underset{5}{\text { Much better }}$ \\
\hline $\begin{array}{l}\text { Alclofenac } \\
\text { Phenylbutazone }\end{array}$ & $\begin{array}{r}10 \\
3\end{array}$ & $\begin{array}{l}7 \\
6\end{array}$ & $\begin{array}{r}6 \\
14\end{array}$ \\
\hline
\end{tabular}


Table III Patient preferences

\begin{tabular}{|c|c|c|c|c|c|}
\hline & No preference & $\begin{array}{l}\text { Phenylbutazone } \\
\text { preferred }\end{array}$ & & Alclof & ac preferred \\
\hline \multirow{2}{*}{$\begin{array}{l}\text { 1st treatment } \\
\text { alclofenac } \\
\text { 1st treatment } \\
\text { phenylbutazone }\end{array}$} & 1 & \multicolumn{2}{|l|}{5} & \multicolumn{2}{|l|}{1} \\
\hline & 2 & \multicolumn{2}{|l|}{11} & \multicolumn{2}{|l|}{3} \\
\hline \multicolumn{2}{|l|}{ Total } & \multicolumn{2}{|l|}{16} & \multicolumn{2}{|l|}{4} \\
\hline \multirow{4}{*}{\multicolumn{2}{|c|}{$\begin{array}{l}\text { on phenylbutazone. Using the ' } t \text { ' test for paired } \\
\text { dependent values no differences were shown either } \\
\text { between treatments or comparing these with the } \\
\text { initial assessments. } \\
\text { There is no evidence that order of treatment } \\
\text { affected patient preference, and comparing the ratio } \\
\text { of phenylbutazone/alclofenac preferences by Fisher's } \\
\text { exact test shows this to be significant }(P<0.01) \text { in } \\
\text { favour of phenylbutazone (Table III). }\end{array}$}} & \multicolumn{4}{|c|}{ Table IV Incidence of side-effects } \\
\hline & & Side-effects & \multicolumn{2}{|l|}{ Alclofenac } & Phenylbutazone \\
\hline & & $\begin{array}{l}\text { Rashes } \\
\text { Gastrointestinal } \\
\text { Headache } \\
\text { Miscellaneous }\end{array}$ & \multicolumn{2}{|l|}{$\begin{array}{l}6 \\
8 \\
1 \\
4\end{array}$} & $\begin{array}{l}0 \\
5 \\
0 \\
0\end{array}$ \\
\hline & & Total & \multicolumn{2}{|l|}{19} & 5 \\
\hline
\end{tabular}

\section{Analysis of laboratory results}

There was no difference in the effect of the drugs on white cell count, ESR, glucose, proteins, and electrolytes. A slightly significant $(P<0.05)$ drop in haemoglobulin level on phenylbutazone (11.98 $\mathrm{g} / \mathrm{dl})$ compared with alclofenac $(12.54 \mathrm{~g} / \mathrm{dl})$ was found, and there was a significant rise $(P<0.01)$ in blood urea on phenylbutazone compared with the initial period on paracetamol.

The incidence of side effects has been recorded from all the patients including those who were withdrawn from the trial (Table IV). 'Gastrointestinal' included indigestion, nausea, diarrhoea, and constipation; 'miscellaneous' comprised sleeplessness, dysuria, itching, and anal irritation. Taking side effects as a whole, there was a significant difference in their incidence $(P<0.01)$, more being found during alclofenac treatment.

Rashes were generalized, red, and itchy. They were often described as covering the patient from her scalp to the soles of the feet. Various types were reported (see Table V) and the patient often felt hot and ill. The heat and pruritus responded quickly to antihistamines and the rash settled within a few days of stopping alclofenac. There was rarely a history of previous allergy and generalized exfoliation did not occur.

\section{Discussion}

The results of several assessments in this trial suggest that alclofenac and phenylbutazone are comparable. There was similar pain relief and paracetamol consumption on $3 \mathrm{~g}$ alclofenac and $300 \mathrm{mg}$ phenylbutazone daily. Aylward and Davies (1972) found

Table V Rashes on alclofenac

\begin{tabular}{|c|c|c|c|}
\hline Case no. & Rash & Other effects & Began at \\
\hline 6 & $\begin{array}{l}\text { Generalized macular rash on } \\
\text { trunk }\end{array}$ & Lips tight and dry; pruritus & $10 \mathrm{~d}$ \\
\hline 14 & Generalized rash (no details) & Pruritus & $8 \mathrm{~d}$ \\
\hline 15 & $\begin{array}{l}\text { Purpuric rash on legs (less on } \\
\text { arms) }\end{array}$ & Pruritus & $8 \mathrm{~d}$ \\
\hline 29 & Generalized scarlatiniform rash & Ached; pruritus & $10 \mathrm{~d}$ \\
\hline 31 & $\begin{array}{l}\text { Generalized reddish-purple } \\
\text { eruption }\end{array}$ & $\begin{array}{l}\text { Unwell, feverish, face swollen, } \\
\text { pruritus }\end{array}$ & $8 \mathrm{~d}$ \\
\hline 32 & Generalized macular rash & Pruritus & $3 \mathrm{~d}$ \\
\hline
\end{tabular}


much the same and stated that in the short term alclofenac relieves symptoms as least as effectively as phenylbutazone and appears to be better tolerated. The drug was less well tolerated in the present study, for sixteen patients preferred phenylbutazone and only four alclofenac. This finding correlates with the observation that fourteen patients considered their progress in pain relief to have been better on phenylbutazone. It is probable that in spite of the wording of the question, 'In comparison with the previous weeks, would you say your pain is much worse, worse...e etc.', the patient was interpreting the question globally and not just relating it to pain.

There is some evidence that there was a slightly greater drop in haemoglobin on phenylbutazone than on alclofenac. Specifically designed surveys would be ne cessary to explore this finding.

Six of our thirty-one patients developed generalized rashes on alclofenac. These were not life-threatening and not associated with haemotological changes-in fact there were no significant changes in the haematollogical values monitored in this study. Nevertheless, the rashes were severe enough to discontinue the drug.
They are generally assumed to be allergic, appearing some 8-12 days after treatment is begun, responding to antihistamines and subsiding on withdrawal of the drug.

Previously rashes have been found in $2-4 \%$ of cases. Famaey and Colinet (1971) found rashes in $2 \%$ of the 768 patients treated and Aylward (M. Aylward, personal communication, 1975) found $4 \%$ in a large longterm survey. Recently, Mansel-Jones (1974), writing from the Committee on the Safety of Medicines, has drawn attention to the large number of rashes on alclofenac reported to them, some $14 \%$ of which were associated with systemic disturbance. There is a probability that the high incidence of rashes may be associated with a recent change in the formulation of the active principle in tablets rather than in capsules. Tablets are therefore to be withdrawn.

We are indebted to the following: Elizabeth Collins, B.Sc., Medical Statistician, Bath Medical School, for statistical analysis; Dr. J. F. Hort and Mr. F. Harding of Berk Pharmaceuticals, and to Berk Pharmaceuticals who supplied drugs and record cards; and to our secretarial staff.

\section{References}

Aylward, M., And Davies, D. B. S. (1972) Brit. J. clin. Pract., 26, 517 (A double-blind crossover trial comparing a new antirheumatic agent alclofenac with phenylbutazone in chronic rheumatic disorders)

Famaey, J. P., ANd Colinet, E. (1971) J. belge Méd. phys. Rhum., 26, 6 (Étude clinique de l'association bufexamacalclofenac dans les affections d'origine rheumatismale étude coopérative)

MANSEL-JoneS, D. (1974) Brit. med. J., 1, 160 (Adverse reactions to alclofenac)

Roncucci, R., Simon, M. J., Lambelin, G., Saquet, M., Gillet, C., van Cauwenberge, H., Lefèbvre, P., Daubresse, J. C., ANd BuU-HoI, N. P. (1971) Europ. J. clin. Pharmacol., 3, 176 (Kinetic studies on the absorption and excretion of 4-allyloxy-3-chlorophenylactic acid (Alclofenac) in man)

VAN Hoek, J. (1970) Curr. ther. Res., 12, 551 (Double-blind comparison between 4-allyloxy-3-chlorophenylacetic acid (Alclofenac) and phenylbutazone in osteoarthritis)

Wright, V., WAlker, W. C., AND MCGuIre, R. J. (1969). Ann. rheum. Dis., 28, 157 (Indomethacin in the treatment of rheumatoid arthritis: A controlled trial comparing indomethacin, phenylbutazone and placebo) 